\title{
RELATION BETWEEN KARST AND FLUVIOKARST RELIEF ON THE SLUNJ PLATEAU (CROATIA)
}

\section{ODNOS MED KRAŠKIM IN FLUVIOKRAŠKIM RELIEFOM, PRIMER SLUNJSKE URAVNAVE}

NEVEN BOČIĆ ${ }^{1}$

\footnotetext{
${ }^{1}$ Department of Geography, Faculty of Science, Marulićev trg 19/II, 10000 Zagreb, Croatia Speleological society Karlovac, Kačićeva 1, 47000 Karlovac, Croatia e-mail: nbocic@geog.pmf.hr
} 


\section{Neven Bočić: Relation between Karst and Fluviokarst Relief on the Slunj Plateau (Croatia)}

The Slunj plateau is part of the shallow Kordun karst. It extends from the westernmost part of river Una towards the northwest to the confluence of the Slunjčica and Korana, at an average height of $300-350 \mathrm{~m}$ of above sea level. It is $40 \mathrm{~km}$ long, and averages about $10 \mathrm{~km}$ wide. A larger part of the plateau of Jurassic and Cretaceous carbonate rocks has characteristics of e karst relief with numerous dolines. On the smaller part of the Paleozoic and Tertiary clastic sediments and Triassic dolomites, a surface fluvial network has been developed. The water streams emerging on that basis regularly disappear underground on contact with permeable rocks. During geomorphological evolution of this terrain the area which is being drained on the surface was reduced, and the traces were left in the form of blind and dry (fossil) valleys. The water streams moved from the surface to underground where they formed the underground channels, i. e. speleological objects. This work analyses the correlation between the formation processes of (today fossil) valleys and cave channels on three examples: 1) Cave system Matešićeva - Popovačka cave, 2) Ponor pod Kremenom cave and Barićeve cave, 3) Cave system Varićakova - Panjkova cave.

Key words: karst geomorphology, fluviokarst, contact karst, caves, Slunj plateau, Croatia.

\section{Izvleček}

UDK: 551.44(497.5)

\section{Neven Bočić: Odnos med kraškim in fluviokraškim reliefom, primer Slunjske uravnave}

Slunjska uravnava je del kordunskega krasa. Ta se razteza v nad. viš. 300-350 m, od najdlje proti zahodu segajočega dela doline Une do sotočja Slunjčice in Korane. Dolga je 40 in povprečno 10 km široka. Večji del te uravnave, zgrajene iz jurskih in krednih karbonatnih kamnin, ima značilnosti kraškega reliefa s številnimi vrtačami. Na manjšem delu, ki ga gradijo paleozojski in terciarni klastični sedimenti in triasni dolomiti, je razvita površinska rečna mre•a. Vodotoki, ki so na tej podlagi, na stiku s prepustnimi kamninami izginejo v podzemlje. Tekom geomorfološkega razvoja tega ozemlja se je površinsko odmakano površje zmanjševalo, sledovi tega pa so ostali v obliki slepih in suhih (fosilnih) dolin. Vodni tokovi so se s površja prestavili v podzemlje, kjer so izdolbli podzemeljske kanale, to je speleološke objekte. Delo analizira odnos med procesi, s pomočjo katerih so nastale (danes fosilne) doline in jamski rovi na treh primerih: 1. jamski sistem Matešićeva - Popovačka jama, 2. Ponor pod Kremenom in Barićeve jame, 3. jamski sistem Varićakova - Panjkova jama. Ključne besede: geomorfologija krasa, fluviokras, kontaktni kras, Slunjska uravnava, Hrvaška. 


\section{INTRODUCTION}

The Slunj plateau is a part of the shallow Dinaric karst (Herak et al. 1969) in Croatia (Fig.1), i.e. of its eastern part called the Kordun karst. It spreads from the furthest western flow of the Una River towards the north-west, where the Slunjčica flows into the Korana River at an average height of 300-350 above sea level, is $40 \mathrm{~km}$ long, and, on average, $10 \mathrm{~km}$ wide. North east of Slunj plateau is the zone (approximately SE-NW) representing the transition between Dinaric Karst and Peripanonian non-karst region. It is the meeting belt of two megageomorphological regions (Dinaric and Panonian regions in Croatia; Bognar 2001) or more precisely the subgeomorphological regions of Slunj plateau with the dominating characteristic of the karst relief and Cetingrad hills with fluviodenudational relief characteristics. The present geological characteristics are the result of the complex evolution of the area through the geological past (Korolija et al. 1979; Korolija et al. 1981). Specially important were the intensive processes of thrusts from the north east in the Eocene period. The tectonic structure feels the consequences of the influence of the nappe of Petrova Gora in the north east. At the same time it is a tectonic border of the structural complexes Dinaric and Supradinaric (Herak 1986). Most of the Slunj plateau area is made of carbonate rocks from the Cretaceous, which are mostly limestone. In the north and central part of the plateau there are also Jurassic carbonate rocks. Among the middle and upper-Jurassic carbonates there are mostly limestone, and among the lower-Jurassic carbonates dolomites are dominant. The smaller part of the researched area is built of Paleozoic and Tertiary clastites and Triassic dolomites. Most parts of the Slunj plateau made of limestone rocks have all the typical characteristics of karst relief, with numerous dolines. In areas made of clastites and dolomites, a surface water network was developed, i.e. fluviodenudational relief type. Waterflows which were created on such a ground all sink underground in contact with permeable rocks. During the geomorphological evolution of the terrain, due to the karstification process, the area of surface drainage was reduced, and its traces in the relief remain in the form of dry (fossil) valleys. Waterflows moved from the surface underground, where they formed underground channels, i.e. speleological objects. This study focuses on the connection between the forming processes of the (now fossil) valleys and the cave channels. In this area there are many known caving structures, and for the purpose of developing the topic, three examples are used: the system Matešićeva Popovačka cave and its surrounding relief; caves in the Grabovac valley and its surrounding relief, and the system Varićakova-Panjkova cave and its surrounding relief.

The system Matešićeva-Popovačka cave was, according to data available, known to cavers since 1959, when members of the Speleological section of Mountaineering club Dubovac of Karlovac explored it. After them the system was visited and explored by other Croatian caving societies (Velebit, •eljezničar, and Sutjeska from Zagreb). In 1967 Srećko Bo•ićević visited the system and took photographs of it. The cavers public did not have any map of the cave available, so the members of the SO PD Dubovac reinitiated a systematic exploration and surveying of it in 1997. The length of the channels surveyed was 1041 meters (Jelinić 1998). Members of the SD Karlovac explored other side channels in 2000 so the entire length of the system reached 1246 meters. The system Varičakova-Panjkova cave is mentioned in references as Panjkov ponor Kršlje and Muškina - Panjkova cave. The first known entrance into it for scientific purposes had been done by A. Langhoffer in 1912 (Garašić 1984). A systematic caving exploration of the system was done since 1983 by two teams, independently and at the same time, DISKF and SO 
PDS Velebit from Zagreb. Therefore, two sets of data are available about its length: 9352 meters, according to SO PDSV (Čepelak 1985) and 12385 meters, according to DISKF (Garašić 1991). Geological explorations in this system were conducted by Garašić (1984, 1991a, 1991b, 1995, 1997), Jukica \& Grgić (1984) and Jukica \& Kovačević (1984). The three caves in Grabovac valley were found, explored and surveyed by the members of Speleological society Karlovac in 2000 and 2001 (Baćurin et al. 2001), and in 2002 Bočić explored its morphogenesis.

\section{CAVE SYSTEM MATEŠIĆEVA - POPOVAČKA CAVE AND THE SURROUNDING RELIEF}

This system (Fig. 2 and 5) is located in the north-west edge of Slunj Plateau. Surface water flow is formed in several valleys on the hill named Kremenita glava (Flint Stone Head), 458 meters high, made of Permian sandstone (Korolija et al, 1979; Korolija et al. 1981). At the fault contact with limestone and dolostone of the upper Jurassic, some streams sink underground, while the main flow, Popovac, flows on the surface north-westward, towards the fault contact between limestone and dolostone of the upper Jurassic and the limestone of the lower Cretaceous, and sinks there. The valley of the Popovac stream is about 30 meters wide and is in the shape of a blind valley; here, the entrance to the cave system Matešićeva cave is located. The cave system is developed in limestone of the lower Cretaceous. It is a cave system with 3 entrances, 1,246 meters long. The main channel spreads from the entrance into Matešićeva cave to the entrance into Popovačka cave (in the Korana river canyon) and is 640 meters long. The entrance to Matešićeva cave functions as a periodical ponor (several decades ago it was a permanent ponor), and Popovačka cave functions as a spring (Jelinić 1998). The main passage is 5-10 meters wide and up to 15 meters high in the first $2 / 3$ of the length; while in the final third of the main channel dimensions of section-plane decrease. In the central part of the cave there is a fossil channel (7-8

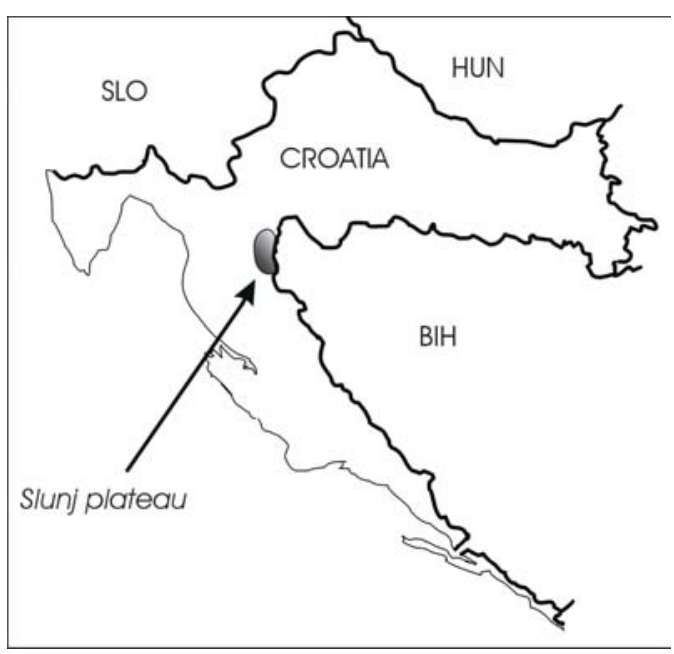

Fig. 1: Location of Slunj plateau. meters above the active one), about 80 meters long, filled with speleothems. The permanent water flow comes through a siphon at about 200 meters from the entrance into Matešićeva cave. From the end of the blind valley of the Popovac stream, there is a fossil (dry) valley, spreading about 400 meters N-NW to the Korana river canyon. It is the remnant of the surface flowing away of the Popovac stream before karstification and the formation of the Matešićeva - Popovačka cave system. Cave water passages (younger than the fossil part of the valley) spread almost entirely under the fossil part of the valley, which indicates that they were probably predisposed by the same tectonic subvertical fault line, with orientation 150 ş - 330ş. 


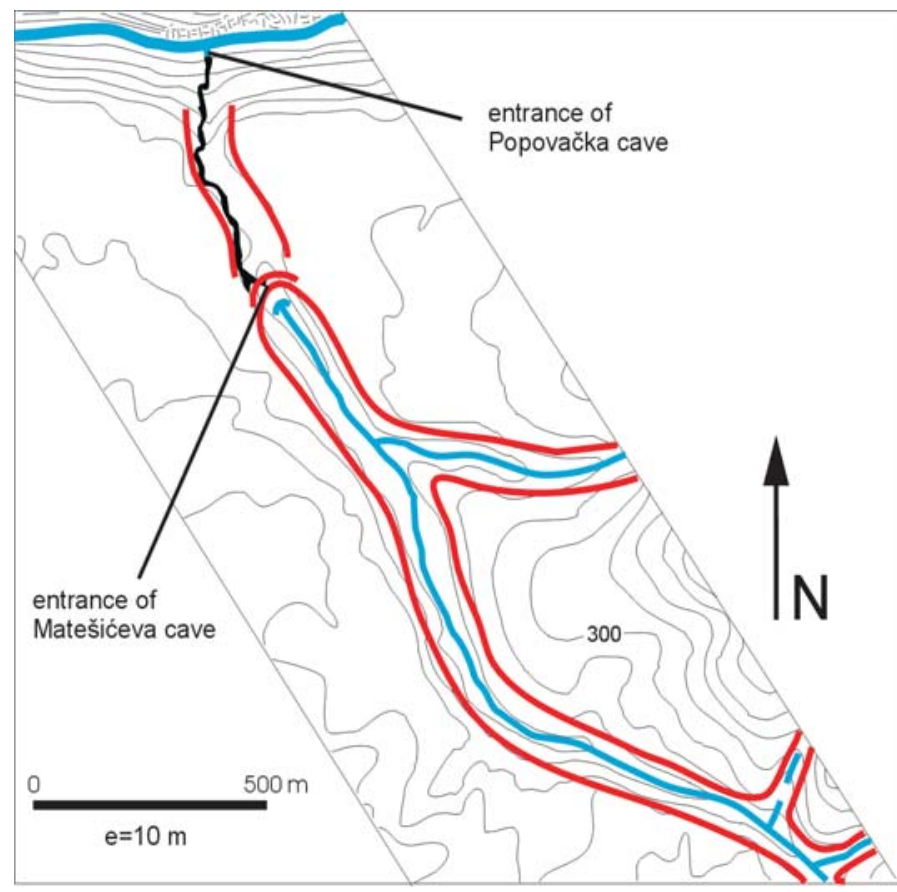

Fig. 2: Cave system Matešićeva - Popovačka cave and its surrounding relief (see fig. 5 for legend; cave channels after Jelinić 1998).

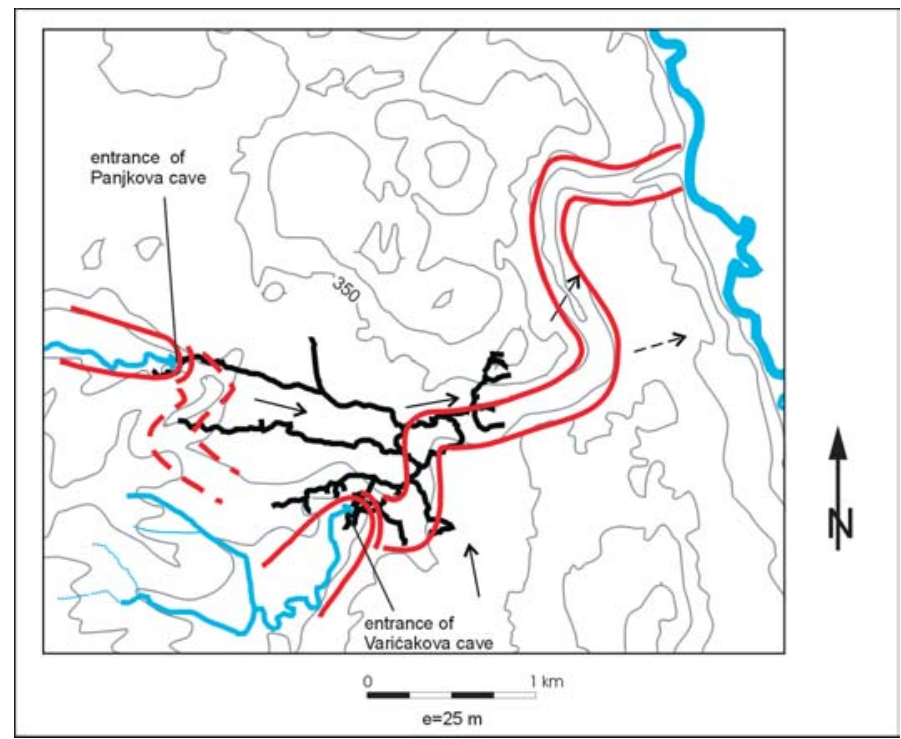

Fig. 3: Cave system Varićakova - Panjkova cave and its surrounding relief (see fig. 5 for legend; cave channels after Garšić 1991).

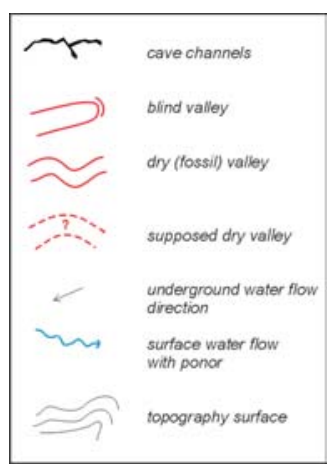

Fig. 5: Legend for fig. 2, 3 and 4. 


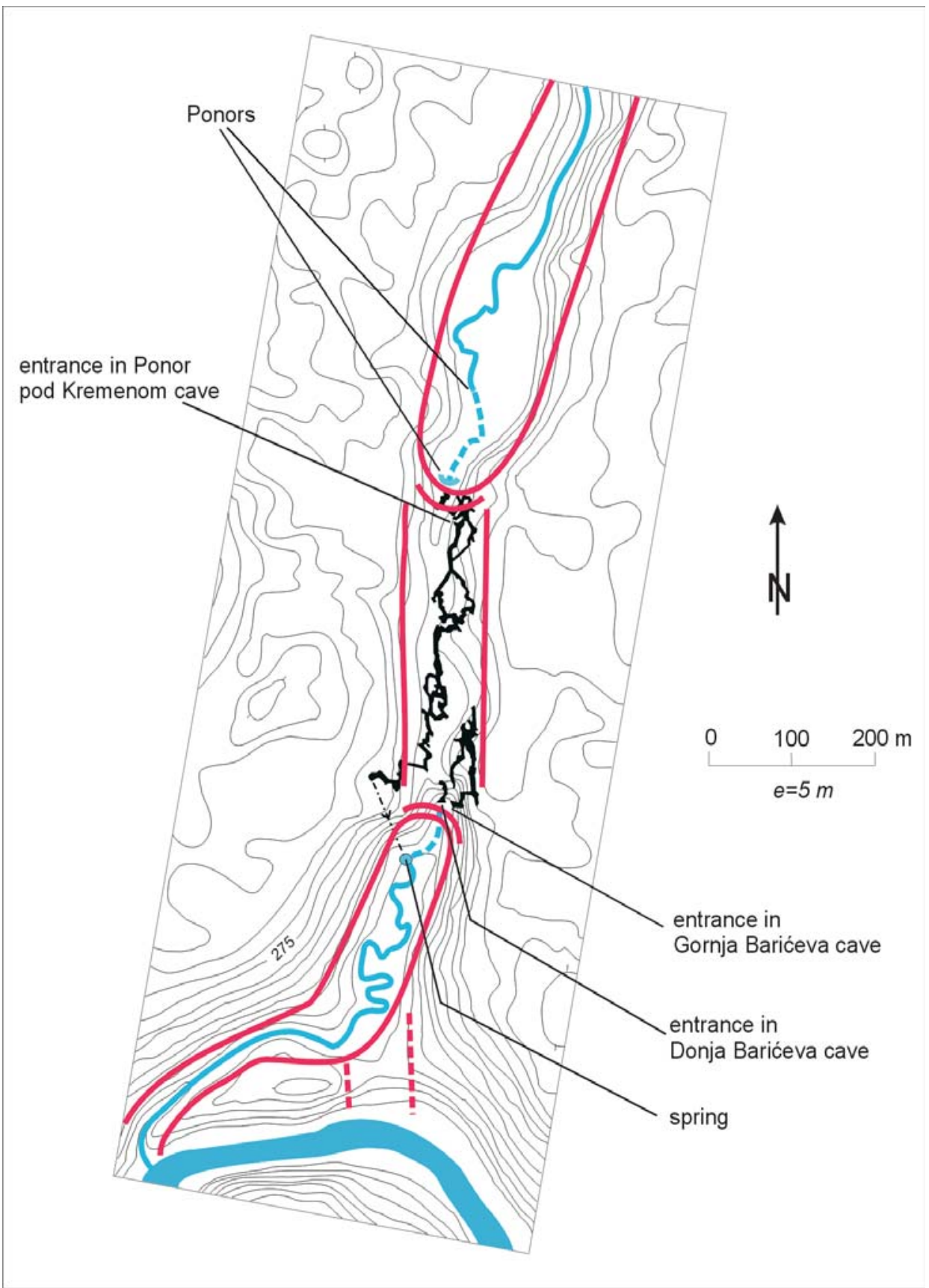

Fig. 4: Caves in the Grabovac valley and its surrounding relief (see fig. 5 for legend; cave channels after Baćurin et al. 2001). 


\section{CAVE SYSTEM VARIĆAKOVA - PANJKOVA CAVE AND THE SURROUNDING RELIEF}

Cave system Varićakova - Panjkova cave (Fig. 3 and 5) is located in the central part of the Slunj plateau. On the impermeable ground made out of impermeable Miocene layers (Korolija et al. 1979; Korolija et al. 1981), there are two major water flows, Perlinac stream (flowing eastward) and Kršlja stream (flowing northward). These layers lie in a transgressive contact on the carbonate layers from the Cretaceous (Korolija et al. 1979; Korolija et al. 1981). In the zone of contact, the streams Perlinac and Kršlja sink underground and their flows continue underground through the cave system Muškinja - Panjkova cave (Čepelak 1985; Garašić 1984). It is the second longest cave system in Croatia, over 12,385 meters long (Garašić 1991 b). The underground passages of this system were developed in the limestone of the lower and upper Cretaceous. By tracing underground water flows it was determined that water appears in the springs on the left side of the Korana river canyon, north-east of the ponors (Garašić 1997). Behind the Perlinac ponor (entrance into Panjkova cave), we can see in the relief the possible spreading of the fossil valley towards the entrance into Varićakova cave, where it was connected with the valley of the Kršlja stream. It created the shape of the letter " $Z$ ", around 1,800 meters long and supposedly 50 meters wide. From the ponor of the Kršlja stream (where the entrance into Varićakova cave is, functioning as a periodical ponor; Jukica \& Kovačević 1984) it continues to the Korana river canyon as a dry valley Krivodol (around $4.7 \mathrm{~km}$ long and up to 50 meters wide). In spite of multiple elbow-shaped turnings, it generally spreads north-eastward. The dry valley Krivodol is a trace in the relief of the surface flowing away of the Kršlja stream (it is possible that the Perlinac stream flowed into Kršlja on the surface, somewhere in the area of the entrance into Varićakova cave). The cave system has a complex morphology (with elements of networking storey and system types), at places of anastomotic or maze morphology. The water passages of Panjkova and Varićakova caves converge underground, where water flows come together, but downstream, passages branch out again under the influence of the fault which lies almost perpendicular to the flowing away direction (Garašić 1984). Besides creating conditions for cave genesis by lowering local erosion basis, neotectonics had a huge influence on the genesis: the uplifting of Mašvina hill north of the system (Garašić 1984), the subsidence of the area of the present valleys of Perlinac and Kršlja streams, and different movements of other tectonic blocks in the area.

\section{CAVES IN GRABOVAC VALLEY (PONOR POD KREMENOM, GORNJA AND DONJA BARIĆEVA CAVE) AND THE SURROUNDING RELIEF}

This area is about $4 \mathrm{~km}$ east of Slunj at the north part of Slunj plateau. The Grabovac valley area is built of Mesozoic carbonates, Cretaceous and Paleocene flysch and Miocene marls, clay and sandstone. Flysch sediments lie on carbonates in transgressive contact. Miocene clastic sediments lie over the older sediments in transgressive contact. The Grabovac stream flows from the north to the south through the valley which is about $50 \mathrm{~m}$ deeper than the surrounding area (Fig. 4 and 5). Partially the Grabovac stream flows underground. It sinks about $1000 \mathrm{~m}$ before it flows into the Korana and later springs again about $325 \mathrm{~m}$ in the south. This part of the valley is dry (fossil). Ponor pod Kremenom is the biggest cave in the Grabovc valley. Main channel generally extends from the north to the south under the dry part of the valley but it forks at several 
points. The underground part of the Grabovac stream flows through its channels. It represents a typical anastomotic morphology. The total length of the channels in Ponor pod Kremenom is 1019 $\mathrm{m}$. In the south of the dry part of the valley are two caves. Gornja Barićeva cave spreads towards the north and the total length of the cave channels is $260 \mathrm{~m}$. It is supposed that it is an old (fossil) spring. Donja Barićeva cave is a simple object $26 \mathrm{~m}$ long. It is supposed to be connected with the main channel in Ponor pod Kremenom. The cave periodically functions as a spring. The formation of these caves is connected to the underground flow of the Grabovac stream. Morphological characteristics of these caves are the result of the influence of allogenic water flow (the Grabovac stream) where the cave channels conduit water which sinks at the end of the active part of the valley. Morphological characteristics of outside relief indicate that the Grabovac stream flew on the surface to the stream mouth into the Korana river. Subsequently due to combined influences of the lowering of the erosion basis and uplifting of the part of Grabovac valley the stream started to sink and a part of the valley become dry.

\section{CONCLUSION}

The main exogenous processes which create the relief of the Slunj plateau are of the karstic, fluviokarstic and fluviodenudating kind. The greatest part of this area is made up of carbonate rocks, dominated by the karst process (Ford \& Williams 1994); in areas built of impermeable rocks, fluviodenudational processes dominate, while in the area of contact between carbonate and non-carbonate rocks, fluviokarst is developed (Gams 1986). The areas of contacts between carbonate and non-carbonate rocks are on faults and transgressive. In the transgressive contacts, because of denudation, the area of non-carbonate rocks decreases, and carbonates at the bottom are revealed, thus increasing the area affected by processes of karst and fluviokarst. Before the process of karstification, the exogenous modeling of the area was fluviodenudational kind, and the drainage was on the surface. High level of erosion basis and mostly gentle inclination of slopes did not permit deep carving of valleys and canyons or the underground sinking of the water flows. The water flows created on impermeable ground are of allogenic kind in toward the surrounding areas made of carbonate rocks. The fractures in these rocks were not widened enough to allow the free flowing of the underground waters.

The tectonic fractures and bedding-planes in the rocks beneath valleys were widened by means of corrosion to dimensions sufficient for turbulent water flows. During further developments of the relief, through the entrenching of the river Korana canyon, the local erosion basis was lowered and the hydraulic gradient was increased. The conditions for allogenic water flows sinking underground were created, and the main phase of the speleogenesis began (Palmer 2001). Because of widening of cave channels and lowering of erosional basis ratio of erosion in speleogenetic process increase. The underground flowing away was no longer conditioned by the incline of the slopes as on surface; the role of the fractures and bedding-planes in directing the flows was increased. In the underground breaking through, the water seeks the most favorable options, thus making the flow changeable, which results in anastomotic morphology and elbow-shaped turnings of cave passages (Palmer 2001). Neotectonic activities have a huge influence on the morphogenesis of the cave passages, which is distinctly obvious in Varićakova - Panjkova cave system ( the uplifting of Mašvina hill, the downthrow of the active parts of valleys). 
With such development of the relief, the lowest parts of a valley became dry, i.e. fossil valleys as traces of the former surface flows. Parts of valleys which retain their active function re-shape themselves into blind valleys. Although these processes are conditioned by the contact of permeable and impermeable ground, the sinking underground does not always happen at the point of contact itself, but also further downstream, where it was tectonically predisposed. With time, a more intense karstification occurs, followed by the retreating movements of the ponors and the atrophy of the function of the oldest ponors (today, water sinks underground in the Matešićeva cave only during maximum water level, and in Muškinja only during extremely high level every couple of years). As consequences of these changes, in geomorphological sense, we can observe few parts of geomorphological - hydrological system in contact karst conditions of Slunj plateau:

- impermeable area of fluviodenudational relief on which the water flow forms witch creating its own valley, and a possible continuation of that valley in carbonate rocks in the shape of a blind valley

- the ponors area with several generations of sinkholes (younger ones are further upstream)

- speleological objects (caves) formed by the corrosion-erosion processes of the underground flow, which can have several levels of passages, as a consequence of the lowering of local erosion basis and neotectonic raising

- dry (fossil) valleys as the remains of the past surface flowing away, with different degrees of karstification

\section{REFERENCES}

Baćurin, •., Balaš, Z., Bočić, N., Cvitanović, H. \& Dubravčić, V., 2001: Maps of Ponor pod Kremenom cave and Barić's caves near Slunj. Archive of Speleological society Karlovac, unpublished

Bognar, A., 2001: Geomorfološka regionalizacija Hrvatske. Acta Geographica Croatica Vol. 34, 7-29, Geografski odsjek PMF, Zagreb

Čepelak, M., 1986: Špiljski sustav Panjkov ponor - Kršlje. Speleolog, vol. XXX-XXXI, 21-27, Speleološki odsjek PD •eljezničar, Zagreb

Ford, D. \& Williams, P., 1994: Karst Geomorphology and Hydrology. Chapman and Hall, London Gams, I., 1986: Kontaktni fliviokras. Acta Carsologica 14 -15, str. 71-87, IZRC-SAZU, Ljubljana

Garašić, M., 1984: Neotektonske aktivnosti kao jedan od uzroka geneze i morfologije jednog od najvećih spiljskih sistema u Hrvatskoj. 9. jugosl. speleološki kongres, Zbornik radova, SDH, 457-465, Karlovac

Garašić, M., 1991a: Morphological and Hidrogeological Classification of the Speleological Structures (caves and pits) in the Croatian Karst Area. Geološki vjesnik 44, 289 -300, IGI, Zagreb

Garašić, M., 1991b: Karstifikacija spiljskog kanala iza Zelelnog sifona i njegova hidrogeološka uloga u spiljskom sustavu muškinje i Panjkove spilje na Kordunu. Spelaeologia Croatica, Vol 2., 5-14, Zagreb

Garašić, M., 1995: Speleogeneza u okviru hidrogeologije krša i procesa karstifikacije. 1. Hrvatski geološki kongres, Zbornik radova, 177-182, Zagreb

Garašić, M.,1997: Karst Water Tracing in Some of the Speleological Features (caves and pits) in Dinaric Karst Area in Croatia. Tracer Hydrology, pp.229-236, Balkema, Rotterdam. 
Herak, M., Bahun, S., \& Magdalenić, A., 1969: Pozitivni i negativni utjecaji na razvoj krša u Hrvatskoj. Krš Jugoslavije 6, JAZU, 45-71, Zagreb

Herak, M., 1986: A New Concept of Geotectonics of the Dinarides. Acta geologica, vol.16/1, 142, Zagreb

Jelinić, I., 1998: Sustav Matešićeva spilja - Popovačka spilja. Speleo’zin 8/9, 3-5, Speleološko društvo Karlovac, Karlovac

Jukica, T. \& Grgić, S., 1984: Komparacija mjerenih tektonskih elemenata u speleološkim objektima i na površini iznad njih. 9. jugosl. speleološki kongres, Zbornik radova, SDH, 443-445, Karlovac

Jukica, T. \& Kovačević, T., 1984: Prirodne podzemne akumulacije pitke vode i njihova zaštita u spiljskim kanalima plitkog krša. 9. jugosl. speleološki kongres, Zbornik radova, SDH, 110-130, Karlovac

Korolija, B., •ivaljević T. \& Šimunić, An., 1979: Osnovna geološka karta 1: 100000 list Slunj. Savezni geološki zavod, Beograd

Korolija, B., •ivaljević T. \& Šimunić, An., 1981: Tumač Osnovne geološke karte 1: 100000 za list Slunj. Institut za geološka istra・ivanja, Zagreb

Palmer, A. N., 2001: Dynamics of Cave Development by Allogenic Water. Acta Carsologica Vol. 30, 13-32, IZRC-SAZU, Ljubljana

\section{ACKNOWLEDGEMENTS}

I want to thank: Ivan Zagoda and Zlatko Balaš for their help in creating graphic appendix; Dr Mladen Garašić for his help in gathering data and useful suggestions for the development of this paper, and Tamara Trkulja for translation into English.

A special thanks to all fellow cavers (known and unknown) who have spent a lot of time underground and retrieved a lot of data used in this study. 